\title{
Research on the Business Legal Environment of China-India Transportation Infrastructure Investment
}

\author{
$\mathrm{Da} \mathrm{Li} *$ \\ International Business School \\ Yunnan University of Finance and Economics \\ 731477732@qq.com \\ Yufang Qiao \\ International Business School \\ Yunnan University of Finance and Economics \\ 577693784@qq.com
}

\author{
Hong Yi \\ International Business School \\ Yunnan University of Finance and Economics \\ ynyihong@126.com \\ Wei Wang \\ International Business School \\ Yunnan University of Finance and Economics \\ $704234551 @ q q . c o m$
}

\begin{abstract}
The rapid development of the Indian economy has attracted worldwide attention. With the continuous deepening of the Indian government's opening up policy, China's investment cooperation with India has continued to deepen. Cooperation in transportation infrastructure investment has been particularly prominent. China has undertaken a large number of infrastructure projects in India such as roads, railways and bridges. Cooperation has achieved remarkable results. However, due to the incompleteness of the foreign investment access law in India, Chinese companies' investment in India has met with significant barriers. Starting from the business legal environment for investment in transportation infrastructure, this article discusses in depth the business legal issues of India's investment environment and investment access, and proposes corresponding countermeasures to provide guidance and reference for cooperation and exchanges between China and India in the field of transportation infrastructure.
\end{abstract}

Keywords-India's transport infrastructure; investment access; bilateral cooperation

\section{INTRODUCTION}

China and India have a good economic and political foundation. In recent years, the volume of trade in goods and services and the scale of trade between China and India have continued to grow. The government has also actively guided the development of trade and economic cooperation between the two countries. China's investment in India's transportation infrastructure is also a manifestation of China's adherence to the "One Belt and One Road" initiative. It can also use India's influence in the South Asian Economic Circle to promote the interconnection of China's economy with countries along the route. India's economy ranks among the top in the world, but India's transportation infrastructure is generally lagging behind. According to India's "Twelfth Five-Year Plan", the Indian government will focus on the construction of infrastructure, and it is estimated that it will invest 56 trillion rupees to promote the improvement of infrastructure and regard it as a driving force for economic restructuring. With China's implementation of the "Belt and Road Initiative" and the establishment of the Asian Investment Bank, China expects to invest approximately 20 trillion rupees in India's transportation infrastructure, and India will usher in a greater round of investment and its infrastructure will be achieved Greater improvement and development.

\section{ANALYSIS OF CHINA'S INVESTMENT IN INDIAN TRANSPORTATION INFRASTRUCTURE}

Since 2005, China and India have begun to implement a cooperation model for the full implementation of transport infrastructure, and China and India have reached consensus on opening up the air cargo market and other fields. Since then, China and India have continuously strengthened various cooperation and cooperation has been particularly prominent in areas such as transportation infrastructure construction. In December 2010, China and India reached an agreement to establish a strategic economic dialogue mechanism between China and India for the investment of Chinese companies in infrastructure and other fields in India. It provided effective mechanism guarantees; in November 2012, China and India signed cooperation memoranda in the fields of railways, highways, industrial energy efficiency, and investment agreements amounting to 311.8 billion rupees.

China and India's investment in roads and railways has become a key area for China-India transport infrastructure cooperation; civil aviation will become a new highlight of infrastructure cooperation. Due to the long period of infrastructure investment, large capital requirements, and high technical requirements, state-owned enterprises have become

\footnotetext{
*Corresponding author
} 
the main force in investing in Indian transportation infrastructure.

In respect of road construction: At present, there are more than 9 Chinese companies participating in the construction and maintenance of 6 highways in India, totaling 24.8 billion rupees. China Longjian Road \& Bridge Co., Ltd. took part in the construction of some highway projects in Gujarat state, and the construction cost was about 430,000 rupees. Afterwards, it signed two bid road construction projects with Himachal Pradesh, totaling approximately 700 million rupees. China Railway Construction is the largest railway and highway construct company in China, and its investment in Indian highway projects is as much as 300 billion rupees [1].

In terms of railway construction: Since 2007, China has exported a large number of railroad equipment to the entire subway vehicle in India [2]. In 2010, DMRC purchased 15 subway trains from Zhuzhou CSR, and in 2016, Delhi Railways (DMRC) purchased 21 subway trains from China South Locomotive Zhuzhou Electric Locomotive Co., Ltd. After December 2014, the Indian high-speed rail company issued a global bid for the feasibility study of the above three high-speed rail lines, and a total of seven countries including China participated in the bid. The first railway plant established by CRRC in India was officially put into operation in December 2016 [3].

In terms of airport construction, the current cooperation between China and India in airport construction is limited to a number of small projects subcontracted during airport construction. In October 2008, Shanghai Urban Construction Group undertook the New Delhi Metro Airport Express project with a contract value of approximately 450 million rupees. This is also the first EPC general contracting project of Shanghai Urban Construction Group in India.

From the above-mentioned status of China-India traffic infrastructure, China has achieved relatively remarkable results in investment in roads and railways, but cooperation in the construction of airports and other projects is not deep enough, especially in important infrastructure construction projects such as ports. India is not completely open to Chinese companies. There are many reasons for this situation. India's complex business legal environment and government intervention are the main factors.

\section{ANALYSIS OF THE LEGAL ENVIRONMENT OF CHINA'S TRAFFIC INFRASTRUCTURE INVESTMENT IN INDIA}

\section{A. Investment Access}

Automatic approval and government approval are currently the main methods of foreign investment approval in India. Automatic approval means no government approval, and foreign investment can be directly invested. The Reserve Bank of India is the agency responsible for automatic approval. The bank is also the central bank of India. Since India is a country that has foreign capital legislation based on foreign exchange legislation, India's central bank's rights are not only limited to the management of the foreign exchange market, but also have the right to manage foreign capital. All foreign capital under automatic approval must be reported to the bank. The main responsible agency approved by the government is the Foreign Investment Promotion Committee. When foreign governments perform government approvals, they must submit their approval materials to the Foreign Investment Promotion Committee. The Foreign Investment Promotion Committee will make a reply within 45 days of entering or not [4].

\section{B. The Proportion of Investment}

India's restrictions on the proportion of foreign investment, there is no uniform standard in the industry, but different standards for different industries, for the transport infrastructure investment in foreign investment ratio standards are not the same. The specific proportions are as follows:

TABLE I. INDIAN FOREIGN INVESTMENT IN TRANSPORT INFRASTRUCTURE INDUSTRY POLICY

\begin{tabular}{|c|c|c|}
\hline $\begin{array}{c}\text { Industrial } \\
\text { Classification }\end{array}$ & $\begin{array}{c}\text { Foreign Investment } \\
\text { Holding Limits }\end{array}$ & Approval Route \\
\hline Highway & $100 \%$ & $\begin{array}{c}\text { Automatic approval(investment } \\
\text { no more than \$350 million) }\end{array}$ \\
\hline Railway & $100 \%$ & $\begin{array}{c}\text { Exceeds } 74 \% \text { of shares must be } \\
\text { approved by FIPB }\end{array}$ \\
\hline ports & $100 \%$ & $\begin{array}{c}\text { Automatic approval(investment } \\
\text { no more than \$350 million) }\end{array}$ \\
\hline airport projects & $100 \%$ & $\begin{array}{c}\text { Exceeds } 74 \% \text { of shares must } \\
\text { be approved by FIPB }\end{array}$ \\
\hline Air Transport & $49 \%$ & Automatic approval \\
\hline Services & & \\
\hline
\end{tabular}

Source: People's Republic of China Ministry of Commerce

Although India has stipulated the proportion of foreign ownership in the infrastructure industry, the approval of foreign-funded projects in the industry has nothing to do with the proportion of foreign-owned equity, and it must be approved by the relevant government departments of India before entering.

\section{Investment Treatment}

As the situation at home and abroad continues to change, India's regulations on investment treatment for foreign investors are constantly adjusted. In 1998, the Ministry of Industry of India established a new policy on encouraging foreign investors to invest in India's transportation infrastructure. In nine industries such as mining, services, metallurgy, electricity, unconventional energy, transportation, and warehousing, the proportion of foreign investment is no more than $74 \%$. The joint venture project application will be automatically approved; the application scope for joint venture projects with a foreign capital ratio of no more than $51 \%$ will be automatically approved, and investments in power generation, distribution, roads, ports, tunnels, bridges, etc., will allow foreign investment not exceeding 15 billion rupees. Under the conditions of the rupee, its equity is up to $100 \%$ and automatically granted [5]. 


\section{Investment Supervision}

India's current foreign investment review system is classified by country and industry. China, Pakistan, and other countries are the targets of India's "focus on care," and India has been implementing differentiated investment treatment for such countries. The standard for industry classification is to screen industries that are important to national security for foreign investment restrictions. Such as infrastructure industry, telecommunication industry, India will restrict or prohibit the entry of foreign capital. This kind of "blacklist" regulatory system is undoubtedly a discriminatory barrier for foreign investors. If foreign investors cannot enter India through automatic approval channels, it must be approved by the Indian government. In fact, India's approval rate for government approval is very low. The Indian side will always reject entry of foreign investors on various grounds that are detrimental to Indian national security. Even if some investors have passed the automatic approval, the Indian side will conduct another government review. Once the review fails, it will still be unable to enter India for investment.

\section{E. Investment protection}

Since India introduced foreign capital in the 1960s, it has always attached great importance to protecting the interests of foreign investors. The four foreign capital laws promulgated by India contain provisions for the protection of foreign investors. And its protection can be divided into the following three:

\section{1) Production protection}

Chapter 27 of the "Foreign Investment Promotion Act" of India stipulates that foreign-funded enterprises can determine all their own production problems, including their development plans, production and business activity plans, establishment of financial management systems and other operating systems, etc. [6]

\section{2) Profit protection}

Chapter 18 of the Indian Foreign Investment Encouragement Law stipulates that legal profits and investment profits obtained by foreign companies in India are protected by law; legitimate income earned by foreign companies can be freely converted into foreign exchange market after tax payment The currency of other countries; if the taxes, tax rates, or taxation methods that foreign-funded enterprises are required to impede their profitability, the government has the right to order the relevant departments to take remedial measures, regardless of whether the company gives opinions or not [6].

\section{3) Protection against difficulties}

Chapter 48 of India's Foreign Investment Encouragement Law stipulates that if foreign-funded enterprises are inconsistent with domestic companies in the course of their operations, or encounter problems and obstacles that are difficult to manage, the government will continue to operate foreign-invested production activities. The right to issue appropriate assistance orders and to order the relevant authorities to quickly rescue them. For any order issued by the government, any departmental agency must implement it. If it cannot be implemented, it must submit a statement to the government within 10 days after receiving the order. The government can take other measures until the problem is solved [6].

\section{PROBLEMS IN THE BUSINESS LEGAL ENVIRONMENT OF INDIAN TRAFFIC INFRASTRUCTURE INVESTMENT}

The cooperation between China and India in transport infrastructure construction in recent years has achieved remarkable results. Both of them are rising powers that have attracted world attention in recent years. However, the national conditions of the two countries are quite different. China has undergone nearly 40 years of reform and opening up and has formed a relatively complete infrastructure network and development model. However, India has a very large upswing in terms of foreign investment access laws and infrastructure construction. If India cannot solve these problems well, it will definitely affect its development and it will also be detrimental to the entire Asian region. .

\section{A. India's National Security Review is too Strict to Hinder}

\section{Cooperation between the Two Parties}

India often hinders the entry of Chinese enterprises on the grounds of threatening its national security. Huawei, Shenzhen CIMC Tianda Airport Equipment Company, Haier Group and other companies have all been prohibited by India from investing in national security.

Because telecommunications equipment manufacturers and infrastructure construction industries are important for national security and economic development, they are listed as "sensitive industries" by India and various access restrictions have been set. Most investors in the industry in China are affected by this regulation. For example, the CIMC Tianda Group has undertaken many bridge construction projects in India but it is unable to obtain a contract for the construction of an Indian airport due to national security issues. The national security issue has become the biggest obstacle to the further cooperation between China and India.

\section{B. The lack of unified planning for China-India \\ Transportation Infrastructure Cooperation}

China and India have more frequent cooperation in highway, airport, railway and bridge construction. However, due to the imperfections of investment laws in India and the varying degrees of restrictions on various investment projects in China, the cooperation between the two countries in terms of transport infrastructure is not smooth. The Pan-Asian infrastructure plan put forward by the United Nations in 1992 was mainly aimed at improving the transport infrastructure in Asia. China and India are both important participating countries. However, in implementing links, India only cares about its own infrastructure construction, and it lacks The common development of regional understanding [7]. This lack of sincere cooperation model will inevitably make further cooperation between the two countries more difficult. 


\section{Single Sino-Indian Bilateral Transportation Infrastructure} Cooperation

China-India highway construction and a few railway constructions are currently the most important transport infrastructure cooperation modules, and aviation and port areas are less involved. Judging from the current results, the cooperation in highway and railway construction has made great progress. India has begun to introduce high-speed rail in China. However, there are very few Sino-Indian cooperation in the construction of aviation and ports. India, as a maritime power, has $95 \%$ of its trade contacts relying on shipping. Port construction has become an important basis for India's further development of foreign trade. However, it is very difficult for Chinese companies to undertake Indian port construction projects. The bidding for many ports in India prohibits the participation of companies in China and West Asia, mainly due to reasons of national security. In light of this consideration, such a prohibition has also created a barrier of cooperation between China and India in infrastructure construction and investment.

\section{SUGGESTIONS FOR IMPROVING THE BUSINESS LEGAL ENVIRONMENT FOR INDIAN TRANSPORT INFRASTRUCTURE INVESTMENT}

\section{A. Choose to Invest in Bypassing the Risk of National}

\section{Security Review}

Although India's efforts to attract foreign investment have been increasing year by year, India's selective investment policy has also resulted in the differentiation of investment treatment in various countries. Therefore, it is a good choice to set up a company in a friendly relationship with India through the "curve to save the country" and then invest in India through the company. This can also prevent India from prohibiting the entry of foreign investors on the ground of "national security" to some extent. Take Mauritius as an example. In addition to signing a lot of trade bilateral preferential agreements between the two countries, the country is also a close trade country with India. Therefore, most investors choose to set up a holding company in Mauritius first. In order to attract foreign investment, Mauritius will give these foreign-funded enterprises a zero tax rate or a low tax rate based on the type of investment and projects of the company, which greatly reduces the number of foreign investors wanting. It is difficult to enter India for investment.

\section{B. Strengthening Regional Connectivity and in-depth}

\section{Multilateral Cooperation}

In recent years, with the continuous deepening and influence of the opening up to the outside world, India's development speed has surpassed China in some aspects. Regional cooperation is also one of the fundamental means for the development of a country or a region. At present, the slow development of transportation infrastructure has severely constrained the acceleration of India's economy or society. At present, the road facilities in India are completely unable to meet the conditions for development, and the railways also need a large number of reconstruction work. The expansion of the port is imminent. In 2011, China planned to invest 20 trillion rupees in India for the construction of India's infrastructure, while the Indian side was hesitant. India's "national security" precautionary standards, which severely restrict the entry of Chinese capital, have hindered its own development while affecting cooperation between the two countries. It is suggested that India relax its irrational alert on China and strengthen communication and cooperation. Only cooperation can win together.

\section{Utilizing China-India Infrastructure Construction to}

\section{Expand Collaborative Approaches}

With the continuous deepening of reform and opening up, China's infrastructure network has basically taken shape. The factors that have constrained economic development have become a booster for China's rapid economic growth. In the decades of construction, China's independent research and development of key technologies and rich practical experience have made us a world leader in infrastructure construction. Even though India has experienced nearly 30 years of development, the backwardness of transportation infrastructure has not been improved, and the gap in transportation hardware facilities has continued to increase with the demand of Indian residents, and India is currently unable to solve this problem. Problems must be found through cooperation.

India can promote the development of its own transport infrastructure construction and advancement of technology through in-depth cooperation with China and making full use of China's advanced technologies and experience in infrastructure construction.

\section{ACKNOWLEDGEMENT}

In this paper, I would like to thank Professor, Yi Hong and Professor, Feng Shake, who gives me much guidance and advice of my writing paper, and helped me complete this paper. I want to express my deep gratitude and blessing to all of you.

\section{REFERENCES}

[1] He Wei. Problems and Countermeasures of Sino-Indian Economic and Trade Cooperation in the Post-Financial Crisis Era[J]. Wuhan University of Science and Technology, South China, 2011(1).

[2] CRRC began to build trains in India but also to set up a railway universityhttp://finance.sina.com.cn/stock/usstock/c/2016-08-27/doc-ifx vixer 7335671.shtml

[3] See Press not No.4 (2006 Series),http://WWW.siadipp.nic.in/policy /changes/

[4] Chinese-made subway cars entered New Delhi again, http://www. mofcom.gov.cn/article/i/jyjl/j/201310/201310003

[5] Wang Hongjun. Research on the Foreign Investment Access System in India: Taking the Investment of Chinese Enterprises to India as an Example.[J].Yunnan University of Finance and Economics,2008(5).

[6] Ren Huizhong. Main Features of Indian Foreign Investment Law [J]. Asia-Pacific Economics, 1991 (02): 36-40.

[7] Yang Wenwu, Xu Fei. Research on Sino-Indian Economic and Trade Cooperation in Post-crisis Era[J]. South Asia Quarterly, 2012(04):69-75+5. 